\title{
FAKTOR YANG MEMPENGARUHI PRICE TO BOOK VALUE
}

\author{
MUWAFICK HIDAYAT \\ STIE Trisakti \\ muwafick@dosen.stietrisakti.ac.id
}

\begin{abstract}
The purpose of this research is to empirically test and analyze the influence of dividend payout ratio, current ratio, return on asset, firm size, debt to equity ratio and asset growth. The object of this research is food and beverages companies listed in Indonesia Stock Exchange in 2011-2016 period. The sample consisting of 7 companies, was selected by means of the purposive sampling technique. The research data is secondary data obtained from Indonesia Stock Exchange (IDX). The results of this research showed that current ratio, return on asset, firm size, debt to equity ratio influence the firm value, while dividend payout ratio and asset growth have no influence on firm value.
\end{abstract}

Keywords: Price to book value, dividend payout ratio, current ratio, return on asset, firm size, debt to equity ratio, asset growth.

Abstrak: Tujuan penelitian adalah untuk menguji dan menganalisis secara empiris pengaruh dividend payout ratio, current ratio, return on asset, firm size, debt to equity ratio dan asset growth terhadap price to book value. Objek dalam penelitian adalah makanan dan minuman yang terdaftar di Bursa Efek Indonesia periode 20112016. Sampel penelitian sebanyak 7 perusahaan yang diperoleh dengan teknik purposive sampling. Data penelitian merupakan data sekunder yang diperoleh dari Bursa Efek Indonesia (BEI). Hasil penelitian ini menunjukkan bahwa current asset, return on asset, firm size dan debt to equity ratio berpengaruh terhadap price to book value, sedangkan dividend payout ratio dan asset growth tidak berpengaruh terhadap price to book value.

Kata kunci: Price to book value, dividend payout ratio, current ratio, return on asset, firm size, asset growth.

\section{PENDAHULUAN}

Sekarang ini dunia investasi sedang berkembang, banyak perusahaan yang gencar mengembangkan usahanya untuk memenuhi kebutuhan modalnya. Perusahaan membutuhkan tambahan modal untuk meningkatkan nilai suatu perusahaan. Suatu perusahaan didirikan untuk mensejahterakan pemegang saham dan memaksimalkan nilai perusahaan. Nilai perusahaan yang tinggi menunjukan harga saham yang tinggi pada perusahaan tersebut. Semakin tinggi harga saham semakin tinggi pula nilai perusahaan, yang sesuai dengan keinginan para pemiliknya, karena dengan meningkatnya nilai perusahaan, maka kesejahteraan para pemilik juga akan meningkat dan akan menarik minat para investor untuk menanamkan modalnya. Salah satu pendekatan dalam menentukan penilaian saham adalah dengan melihat Price to Book Value (PBV). Menurut Brigham dan Houston (2014, 115) Price to Book Value (PBV) digunakan untuk mengukur kinerja harga pasar saham terhadap nilai bukunya. Semakin tinggi Price to Book Value (PBV), semakin baik pasar memandang perusahaan dan prospeknya. Hal ini berarti semakin berhasil perusahaan 
menciptakan nilai bagi pemegang saham. Tujuan penelitian ini adalah untuk mendapatkan bukti empiris mengenai pengaruh dividend payout ratio, current ratio, return on asset, firm size, debt to equity ratio dan asset growth terhadap price to book value.

\section{Signaling Theory}

Menurut Modigliani dan Miller dalam buku Brigham dan Houston (2006) berpendapat bahwa kenaikan dividen yang lebih tinggi daripada yang diharapkan adalah suatu sinyal kepada investor bahwa manajemen perusahaan meramalkan laba masa depan yang baik. Sebaliknya pengurangan dividen atau peningkatan yang lebih kecil dari yang diharapkan adalah suatu sinyal bahwa manajemen sedang meramalkan laba yang buruk di masa depan. Gitman dan Zutter (2015, 586) menyatakan bahwa para investor membutuhkan informasi mengenai kegiatan perusahaan untuk membedakan antara perusahaan yang memiliki nilai tinggi dengan perusahaan yang memiliki nilai yang rendah. Informasi tersebut dapat berupa sinyal positif maupun negatif, dimana perusahaan memberikan sinyal kepada para investor dalam bentuk seperti laporan keuangan dari suatu perusahaan yang akan menentukan cara pandang para investor untuk melakukan investasi atau tidak di perusahaan tersebut.

\section{Agency Theory}

Menurut Gitman dan Zutter $(2015,68)$ agency problem terjadi ketika manajer menyimpang dari tujuan untuk mensejahterakan shareholder dengan mementingkan tujuan mereka terlebih dahulu, akibatnya akan meningkatkan biaya keagenan (agency cost). Agency cost adalah biaya yang ditanggung oleh para shareholder karena menghindari masalah keagenan. Berdasarkan teori di atas, dapat di simpulkan bahwa Teori keagenan merupakan hubungan kontrak yang terjadi antara satu pihak (principal) dan pihak lain (agen) untuk melakukan suatu jasa atau layanan atas nama prinsipal serta memberi wewenang kepada agen untuk membuat keputusan yang terbaik bagi prinsipal. Jika kedua belah pihak tersebut mempunyai tujuan yang sama untuk memaksimumkan nilai perusahaan, maka diyakini bahwa agen akan bertindak dengan cara yang sesuai dengan kepentingan prinsipal.

\section{Price to Book Value Dividend Payout Ratio dan Price to Book Value}

Menurut Hery (2016, 27) Dividend Payout Ratio adalah rasio yang menunjukkan hasil perbandingan antara dividen tunai per lembar saham dengan laba per lembar saham. Menurut Cornett, et al. $(2015,87)$ Dividend Payout Ratio adalah alat ukur kebijakan dividen dimana rasio pembayaran dividen adalah persentase laba yang dibayarkan kepada para pemegang saham dalam bentuk kas. Berdasarkan penjelasan, maka dapat dibangun hipotesis:

$\mathrm{H}_{1} \quad$ Terdapat pengaruh Dividend Payout Ratio terhadap Price to Book Value.

\section{Current Ratio dan Price to Book Value}

Menurut Murhadi $(2015,57)$ Current Ratio adalah rasio yang biaya digunakan untuk mengukur kemampuan perusahaan memenuhi liabilitas jangka pendek yang akan jatuh tempo dalam waktu satu tahun. Menurut Brigham dan Houston $(2014,102)$ Current Ratio merupakan rasio yang digunakan untuk mengukur kemampuan perusahaan dengan membagi aktiva lancar dengan hutang lancar. Berdasarkan penjelasan, maka dapat dibangun hipotesis:

$\mathrm{H}_{2}$ Terdapat pengaruh Current Ratio terhadap Price to Book Value.

\section{Return On Asset dan Price to Book Value}

Menurut Brigham dan Houston (2014, 112) Return On Asset merupakan kemampuan perusahaan memperoleh laba melalui aset yang tersedia. Semakin besar kemampuan perusahaan memperoleh laba maka harga pasar perushaan akan semakin meningkat. Berdasarkan penjelasan, maka dapat dibangun hipotesis:

$\mathrm{H}_{3} \quad$ Terdapat pengaruh Return On Asset terhadap Price to Book Value. 


\section{Firm Size dan Price to Book Value}

Menurut Pramana dan Mustanda (2016) perusahaan yang berukuran besar cenderung lebih mudah untuk mendapat kepercayaan dari pihak kreditur untuk mendapatkan sumber pendanaan sehingga dapat meningkatkan nilai perusahaan. Berdasarkan penjelasan, maka dapat dibangun hipotesis:

$\mathrm{H}_{4} \quad$ Terdapat pengaruh Firm Size terhadap Price to Book Value.

\section{Debt to Equity Ratio dan Price to Book Value} Menurut Kasmir $(2014,157)$ Debt to equity ratio merupakan rasio yang digunakan untuk menilai hutang dengan ekuitas. Rasio ini dicari dengan cara membandingkan antara seluruh hutang, termasuk hutang lancar dengan seluruh ekuitas. Rasio ini digunakan untuk mengetahui jumlah dana yang disediakan peminjam (kreditor) dengan pemilik perusahaan. Dengan kata lain, rasio ini berfungsi untuk mengetahui setiap rupiah modal sendiri yang dijadikan untuk jaminan hutang. Berdasarkan penjelasan, maka dapat dibangun hipotesis:

$\mathrm{H}_{5}$ : Terdapat pengaruh Debt to Equity Ratio terhadap Price to Book Value.

\section{Asset Growth dan Price to Book Value}

Menurut Kasmir (2010, 114) menyatakan bahwa Asset Growth merupakan rasio yang menggambarkan kemampuan perusahaan mempertahankan posisi ekonominya ditengah pertumbuhan perekonomian dan sektor usahanya. Kusumajaya (2011) berpendapat bahwa Asset Growth adalah peningkatan ataupun penurunan dari total aset yang dimiliki perusahaan. Menurut Syardiana dkk. (2015) Asset Growth akan menghasilkan tingkat pengembalian yang semakin tinggi karena pertumbuhan memiliki aspek yang menguntungkan bagi pihak investor. Berdasarkan penjelasan, maka dapat dibangun hipotesis:

$\mathrm{H}_{6} \quad$ Terdapat pengaruh Asset Growth terhadap Price to Book Value.

\section{METODE PENELITIAN}

Populasi dan sampel yang digunakan dalam penelitian ini merupakan perusahaan makanan dan minuman yang terdaftar di Bursa Efek Indonesia (BEI) yang tercatat di BEI terdaftar tahun 2011-2016. Seluruh data yang digunakan dalam penelitian ini merupakan data sekunder yang diambil dari laporan keuangan perusahaan yang terdaftar di BEI. Pemilihan sampel dalam penelitian ini menggunakan metode purposive sampling. Prosedur pemilihan sampel dapat dilihat dari tabel 1 berikut ini:

Tabel 1 Prosedur Pemilihan Sampel

\begin{tabular}{ll}
\hline \multicolumn{1}{c}{ Kriteria Sampel } & Jumlah \\
\hline Jumlah perusahaan makanan dan minuman yang terdaftar di BEI pada tahun 2011-2016 & 16 \\
Jumlah perusahaan makanan dan minuman yang tidak memiliki kelengkapan data laporan & $(3)$ \\
keuangan pada periode 2011 - 2016 & \\
Jumlah perusahaan makanan dan minuman yang pindah sub sektor setelah tahun 2011 & $(1)$ \\
Jumlah perusahaan makanan dan minuman yang datanya mengalami outlier & $(5)$ \\
Jumlah perusahaan makanan dan minuman yang dijadikan sampel & 7 \\
Jumlah periode 2011-2016 & 6 tahun \\
Jumlah sampel data & 42 data \\
\hline
\end{tabular}


Price to Book Value. Price to Book Value adalah alat ukur nilai perusahaan dengan membagi harga per lembar saham dengan nilai buku per lembar saham. Price to Book Value dapat diukur dengan menggunakan perhitungan sebagai berikut

\section{$P B V$ \\ $=\frac{\text { Harga per lembar saham }}{\text { Nilai buku per lembar saham }} \times 100 \%$}

Dividend Payout Ratio adalah alat ukur kebijakan dividen dimana rasio pembayaran dividen adalah persentase laba yang dibayarkan kepada para pemegang saham dalam bentuk kas. Dividend payout ratio dapat diukur dengan menggunakan perhitungan sebagai berikut

$$
D P R=\frac{\text { Outstanding share } x \text { DPS }}{\text { Net income }}
$$

Current ratio merupakan alat ukur likuiditas perusahaan dengan membagi aktiva lancar dengan hutang lancar. Current ratio dapat diukur dengan menggunakan perhitungan sebagai berikut

$$
C R=\frac{\text { Current Assets }}{\text { Current Liabilites }}
$$

Return on asset merupakan kemampuan perusahaan memperoleh laba melalui aset yang tersedia. Return on asset dapat diukur dengan menggunakan perhitungan sebagai berikut Brigham dan Houston (2010, 148):

$$
R O A=\frac{\text { Laba bersih }}{\text { Total asset }} \times 100 \%
$$

Firm Size merupakan ukuran suatu perusahaan dapat ditunjukkan oleh total asset. Firm Size dapat diukur dengan menggunakan perhitungan sebagai berikut

Firm Size $=\log$ (total aktiva)

Debt to Equity Ratio merupakan perbandingan antara total hutang dengan total ekuitas. Leverage dihitung menggunakan (DER) Debt to Equity Ratio dengan rumus

$$
\text { DER }=\frac{\text { Total Debt }}{\text { Total Equity }} \times 100 \%
$$

Asset Growth adalah peningkatan atau penurunan aset yang dimiliki perusahaan dengan melakukan perbandingan antara total aset periode sekarang dengan terhadap total aset periode sebelumnya. Menurut Kusumajaya (2011) Asset Growth dapat diukur dengan menggunakan perhitungan sebagai berikut:

Asset Growth $=\frac{\text { Total aset } \mathrm{t}-\text { Total aset } \mathrm{t}-1}{\text { Total aset } \mathrm{t}-1} \times 100 \%$

\section{HASIL PENELITIAN}

Hasil pengujian statistik deskriptif untuk variabel yang digunakan dalam penelitian ini dapat dilihat pada tabel 2 berikut dan hasil pengujian hipotesis dapat dilihat pada tabel 3 :

Tabel 2 Hasil Statistik Deskriptif

\begin{tabular}{lccccccr}
\hline Variabel & PBV & DPR & CR & ROA & $\begin{array}{l}\text { FIRM } \\
\text { SIZE }\end{array}$ & DER & GROWTH \\
& & & & \multicolumn{5}{c}{ MAn } & 7.280000 & 0.291190 & 1.841667 & 0.118892 & 6.634048 & 0.870896 & 0.191429 \\
Median & 3.635000 & 0.225000 & 1.700000 & 0.090000 & 6.460000 & 0.885000 & 0.160000 \\
Maximum & 47.27000 & 1.460000 & 4.840000 & 0.670000 & 7.960000 & 1.770000 & 0.850000 \\
Minimum & 0.720000 & 0.000000 & 0.510000 & -0.366532 & 5.330000 & 0.210000 & -0.100000 \\
Std. Dev. & 11.01817 & 0.310029 & 0.884644 & 0.146825 & 0.739417 & 0.392348 & 0.177634 \\
\hline
\end{tabular}


Tabel 3 Hasil Uji $t$

\begin{tabular}{lll}
\hline Variabel & t-Statistic & Prob. \\
\hline DPR & 1.633682 & 0.1131 \\
CR & -4.409104 & 0.0001 \\
ROA & -4.554073 & 0.0001 \\
Firm Size & 5.827910 & 0.0000 \\
DER & -7.662378 & 0.0000 \\
Asset Growth & 0.783274 & 0.4398 \\
\hline
\end{tabular}

Berdasarkan tabel diatas, dapat diambil hasil bahwa variabel current ratio, return on asset, firm size dan debt to equity ratio berpengaruh terhadap price to book value. Sedangkan variabel dividend payout ratio dan asset growth tidak berpengaruh terhadap price to book value.

\section{PENUTUP}

Penelitian ini dilakukan untuk membuktikan secara empiris pengaruh Dividend Payout Ratio, Current Ratio, Return On Asset, Size, Debt to Equity Ratio dan Asset Growth terhadap Price to Book Value Pada Perusahaan Makanan dan Minuman yang terdaftar di Bursa Efek Indonesia periode 20112016. Diperoleh kesimpulan sebagai berikut: Tidak terdapat pengaruh Dividend Payout Ratio terhadap Price to Book Value. Hasil penelitian ini berbeda dengan penelitian yang dilakukan oleh Sugiarto (2011) dan Fenandar (2012). Tetapi, sama halnya dengan penelitian Sukirni (2012) dan Nurhayati (2013). Terdapat pengaruh Current Ratio terhadap Price to Book Value.

Hasil penelitian ini berbeda dengan penelitian yang dilakukan oleh Nurhayati (2013) dan Suwarti (2013). Namun, serupa dengan yang dilakukan oleh peneliti Mahendra (2012) dan Prisilia (2013). Terdapat pengaruh Return on Asset terhadap Price to Book Value. Hasil penelitian ini serupa dengan penelitian yang dilakukan oleh Yunita, et al. (2014) dan Herawati (2012). Terdapat pengaruh Firm Size terhadap Price to Book Value. Hasil penelitian ini berbeda dengan penelitian yang dilakukan oleh Dewi (2013). Namun, serupa dengan yang dilakukan oleh peneliti Nurhayati (2013) dan Eko (2014).

Terdapat pengaruh Debt to Equity Ratio terhadap Price to Book Value. Hasil penelitian ini berbeda dengan penelitian yang dilakukan oleh Ogolmagai (2013), Hartono et al. (2013), Kodongo et al. (2014) dan Mahendra dkk. (2012). Namun, serupa dengan yang dilakukan oleh peneliti Ramadan (2015), Kouki dan Hatem (2011), Febrianti (2012), Angga dan Wiksuana (2016), John O dan Amarjit (2012), serta Cheng dan Zuwei (2011). Tidak terdapat pengaruh Asset Growth terhadap Price to Book Value. Hasil penelitian ini berbeda dengan penelitian yang dilakukan oleh Hermuningsih (2013), Hestinoviana et al. (2013) dan Wardjono (2010). Namun, serupa dengan yang dilakukan oleh peneliti Hartono et al. (2013). 


\section{REFERENSI:}

Brigham, Eugene F., dan Joel F. Houston. 2014. Essentials of Financial Management $3^{\text {rd }}$ Edition. Singapore: Cengage Learning.

Brigham, Eugene F. dan Joel F. Houston. 2006. Fundamental of Financial Management: Dasar-Dasar Manajemen Keuangan Edisi 10. Jakarta: Salemba Empat.

Cornett, Marcia M., Troy Adair dan John R. Nofsinger. 2015. Applications and Theory $3^{\text {rd }}$ Edition. New York: McGraw-Hill Education.

Gitman, Lawrence J., dan Chad J. Zutter. 2015. Principles of Managerial Finance 14th Edition. United States of America: Pearson Prentice Hall.

Godfrey, et.al. 2010. Accounting Theory $7^{\text {th }}$ Edition. Australia: John Wiley Sons.

Hartono, Jogiyanto 2013. Teori Portofolio dan Analisis Investasi, BPFE Yogyakarta, Edisi Kedelapan, Yogyakarta. Hery. 2016. Analisis Laporan Keuangan. Jakarta: Grasindo.

Kasmir. 2010. Pengantar Manajemen Keuangan. Jakarta: Kencana Prenada Media Group.

Kasmir. 2014. Analisis Laporan Keuangan. Edisi Satu. Cetakan Ketujuh. Jakarta: PT Raja Grafindo Persada.

Murhadi, Warner R. 2015. Analisis Laporan Keuangan Proyeksi dan Valuasi Saham. Jakarta: Salemba Empat. 